\title{
Study of Factors That Influence the Sustainability of Agricultural Development in the Bobonaro Municipality, Timor-Leste
}

\author{
Graciano Soares Gomes ${ }^{*}$, Carlito De Araújo Mali Code, Vicente De Paulo Correia ${ }^{2}$, \\ Oscar Da Silva², Agostinho Da Cunha Moniz'3 ${ }^{3}$ José Adriano Marçal' ${ }^{3}$, Claudino Ninas Nabais ${ }^{4}$ \\ ${ }^{1}$ Department of Animal Science, National University of East Timor-UNTL, Díli, Timor-Leste \\ ${ }^{2}$ Department of Agro Economic, National University of East Timor-UNTL, Díli, Timor-Leste \\ ${ }^{3}$ Department of Agronomy, National University of East Timor-UNTL, Díli, Timor-Leste \\ ${ }^{4}$ East Timor National Institute of Science and Technology-INCT-TL, Díli, Timor-Leste \\ Email: *graciano_gomes@yahoo.com
}

How to cite this paper: Gomes, G.S., De Araújo Mali Code, C., De Paulo Correia, V., Da Silva, O., Da Cunha Moniz, A., Marçal, J.A. and Nabais, C.N. (2022) Study of Factors That Influence the Sustainability of Agricultural Development in the Bobonaro Municipality, Timor-Leste. Agricultural Sciences, 13, 105-116.

https://doi.org/10.4236/as.2022.132009

Received: December 25, 2021

Accepted: January 27, 2022

Published: January 30, 2022

Copyright $\odot 2022$ by author(s) and Scientific Research Publishing Inc. This work is licensed under the Creative Commons Attribution International License (CC BY 4.0).

http://creativecommons.org/licenses/by/4.0/

\begin{abstract}
The aim of the study is to assess the factors that influence the sustainability of agricultural development. The study was carried out in the municipality of Bobonaro for about four months, from July to October 2021. Slovin's method was used to determine the sample size, with a desired percentage of $10 \%$ of the total population. Thus, 154 producers were interviewed as respondents and key persons in the area of agriculture. The variables interviewed are the main factors of agricultural productivity and the factors that affect sustainable agricultural development. The results of the descriptive statistical analysis of the data showed that about $94.87 \%$ of the respondents' productive area is in operation, with an average of 1.84 ha per respondent and the abandoned area around 0.11 ha per respondent. The average value of rice production is 2.38 ton per ha and corn 1.07 ton per ha. About $87 \%$ of producers raised the main types of animals such as cattle, pigs, goats with an average density of 2 to 5 animals per establishment. About $61 \%$ of producers have access to the market at a normal price for agricultural products. The factors that hinder less successful agricultural development, such as: those of nature with the greatest impact are climate changes, which influence changes in cultivation sessions and in the characteristics of productive soils, availability of water for irrigation and animal feed. On the socioeconomic side, it includes the willingness or interest of young people who want to work as farmers, less investment and the impact of the Covid-19 pandemic. It is concluded that natural and socioeconomic impacts can reduce agricultural productivity, so that this will be a major challenge for the development of the agricultural sector in the future.
\end{abstract}




\section{Keywords}

Land Productivity, Sustentability, Agricultural Production, Factors

\section{Introduction}

The development of the agricultural sector in Timor-Leste began in 2002 after the restoration of independence, the government through the Ministry of Agriculture and Fisheries initiating various types of programs that are critical to eradicating poverty and hunger through sustainable production in large scale in order to ensure sustainable consumption and also guarantee self-sufficient food in the country. However, reality shows that during the 19 years of independence, around $70 \%$ of domestic consumption is still totally dependent on imported products, because domestic agricultural production is still limited.

The results of the Census of Households in Timor-Leste [1] revealed that around $76.29 \%$ of the total number of registered families is involved in agricultural activity in general, that is, their family economy is totally dependent on the agricultural sector. However, the result of the Agricultural Census [2], revealed that there was an increase of about $4 \%$ of new heads of household in four years, which raised the total number of heads of household to 213,417, but on the other hand, there was a decrease of $10 \%$ in the participation in agricultural activities; therefore, in the year 2019 about $66 \%$ of all families were involved in agricultural activities.

The sustainability of agricultural sector growth is a significant source of economic growth in many underdeveloped countries, and it also has the greatest contribution to poverty reduction. The sustainability of agricultural development in several countries can contribute to improving the economy of small food producers in rural areas and also become the main source of the national economy [3]. In the Timor-Leste's Strategic National Development Plan 2011 to 2030 , it emphasizes that a strong agricultural sector is needed to reduce poverty, ensure food security and promote economic growth in rural areas and in the nation as a whole. However, to achieve this goal, the determining factors to ensure its sustainability must be taken into account, namely, the family workforce, product yield, land productivity, market guarantee and fair price, adequate irrigation due to the interdependence between these factors. Without the sustainability of agricultural development, there is no supply of products for food and raw materials for industries, and generation of foreign exchange through the export of agricultural products as complementary income for the country. On the other hand, the environmental issue becomes a serious problem of human concern to ensure its sustainability, as this sector promises to raise a country's economic indexes while at the same time becoming the cause of environmental problems. Therefore, it seeks to harmonize economic development with the preservation of the environment, maintaining good social and environmental rela- 
tions with ecological practices.

As highlighted by Guedes [4], the partial productivity indicators of certain factors support the simplicity of calculation and the availability of information. Agriculture development is facing the pressure to reform the sector towards sustainable development accompanied by greater benefits to farmers and to ensure the $t$ self-sufficient in food to reducing poverty [5]. Denardi [6] describes all human existence, history and culture depend on the land space it occupies or is not allowed to occupy. As defined by the UN Commission on Social, Economic and Cultural Rights [7] poverty should be an entity not only as deprivation of financial resources, but broadly among others. Standard of living and other rights and it is observed that the growth of the agricultural sector is a significant source for economic growth in many underdeveloped countries.

According to the report by Bragagnolo \& Barros [8], between 2007 and 2009 the number of manual tractors facilitated by the government increased from 100 to 2591 units and the number of large tractors from 13 to 315 units in Timor-Leste. In the same period, 133 rice husking units were also distributed to farmers and 31 irrigation systems were rehabilitated. In addition, 5000 silos were installed in Timor-Leste and 32 "minimarkets" were built in the districts to facilitate the marketing of agricultural products. With State intervention in these two decades, there is still a shortage of agricultural production, in this case rice, above all, cannot reduce the volume of rice imports.

Thus, the factor that motivates the choice of this title is the issue of agricultural productivity in the country, revealing that year after year it presented a significant drop, in a way that does not contribute to the eradication of hunger, food security and stimulate the economy of small food producers in rural areas. The study aims to identify and analyze the factors that influence the sustainability of agricultural development, in particular, the productivity of agricultural land and the production of rice, corn, and livestock.

\section{Materials and Methods}

\subsection{Research Site}

The study was carried out in the municipality of Bobonaro for 4 months (July to October 2021). Bobonaro is one of the 12 administrative municipalities in Timor-Leste, except Special Administrative Region of Oecusse Ambeno (RAEOA), located in the western part of the country, along the border with Indonesia. It has 99,832 inhabitants and an area of $1368 \mathrm{~km}^{2}$. Its capital is the city of Maliana which is located $149 \mathrm{~km}$ southwest of Dili, the country's capital. Total areas of agriculture, especially for growing rice is 8575 hectares and the garden area for growing the corn is 4466 hectares [9]. Clearer information about the geography of the Bobonaro municipality can be seen on the map in Figure 1 below.

\subsection{Research Methods}

In this research, the survey method was used with a descriptive and explanatory 


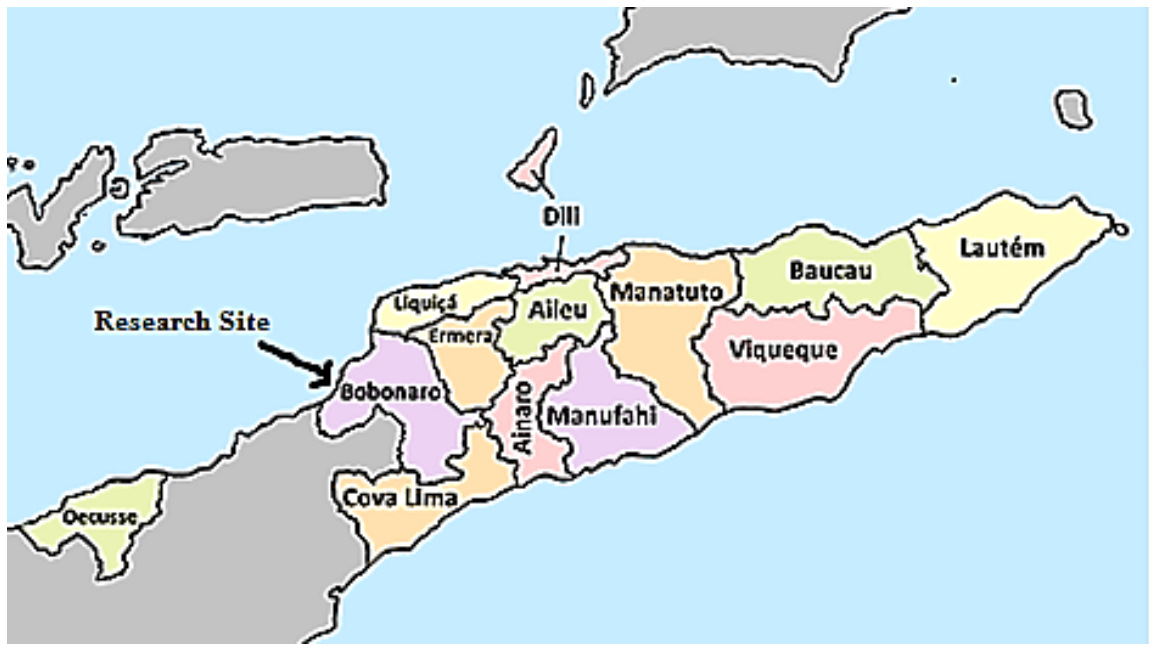

Figure 1. Map of the research Site, in the Municipality of Bobonaro, Timor-Leste.

character, as recommended by Coutinho [10]. To determine the municipality as the research site, the purposeful or intentional sampling method was used based on secondary data from the result of the 2015 Household Census and the 2019 Agricultural Census, with the recommendation of Sugiyono [11], with the formula:

$$
n=\frac{N}{N \cdot d^{2}+1}
$$

which: $n=$ total sample; $N=$ total population; $d^{2}=$ desired percentage (in this research we determined $10 \%$ of the total population.

The total number of farmer families concentrated in the municipality of Bobonaro is 14,465 of farmer household. So the formula is as follows:

$$
n=\frac{14465}{1+14465 \times(0.1)^{2}}=99.99 \approx 100
$$

According to Slovin's formula, the sample size obtained at least 100 farmer families as survey respondents. Therefore, the total sample must be interviewed and observed without limitation, at most, depending on the need for the data necessary for the study. Thus, the variables observed in this study, such as: factors that support agricultural production, main factors of production (size of agricultural areas, productivity, family workforce, investment, effect of climate change, socioeconomic and pandemic effect of Covid-19).

The variables observed in this study are the main factors of sustainable agricultural development, such as size of agricultural areas, land productivity, production of rice, corn, animals, family labor, investment, size of agricultural cultivation areas. Factors affecting less successful sustainable agricultural development as a source of investment, natural factors or climate change, social factors and young people's interest in working as future farmers and the effect of disease Covid-19. 


\subsection{Data Analysis}

The collected data were coded and submitted to a descriptive analysis with an explanatory character to determine the frequencies including mode and relative percentages of factors that influence the growth of agricultural production in the municipality of Bobonaro, based on the recommendations of Coutinho [10].

\section{Results}

The results of the descriptive statistical analysis obtained in this research on the main factors of productivity and factors that influence agricultural development in the municipality of Bobonaro are presented in the Tables and Figures below.

\subsection{The Main Factors of Agricultural Productivity}

\subsubsection{Land}

The survey results revealed that the size of the respondents' productive area is 195 hectares, with 185 hectares in use and 10 hectares are abandoned due to lower working capacity and production facilities. The production areas are private property since the visas. Some were acquired by the respondents themselves. Details of the information are found in Table 1.

Classification according to the size of the productive area is shown in Figure 2. These data showed that more than $57 \%$ of respondents have only the size of the productive area between 0.5 to 1.9 hectares, about $36.36 \%$ of respondents have a productive area between 2 to 3.9 hectares and only $6.49 \%$ of respondents have a productive area between 4 and 10 hectares.

The productivity of the productive area is used only once a year, with rice production of 2.8 to 3.0 tons per harvest. Economically, productivity is the main indicator that relates production values to the factors used. The description of the size and average of agricultural areas per respondent is shown in Figure 3.

The average productive area used by each respondent is 1.84 hectares, which means that $93.88 \%$ of the general average at the municipality level, which is about 1.96 hectares per family, is being used well.

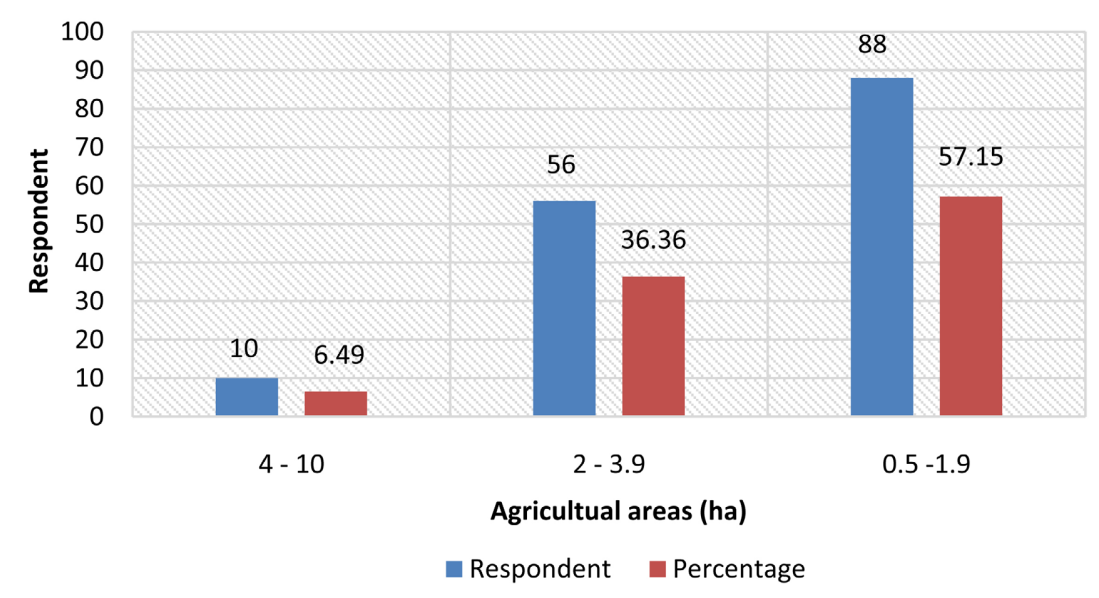

Figure 2. Classification of respondents' agricultural areas. 


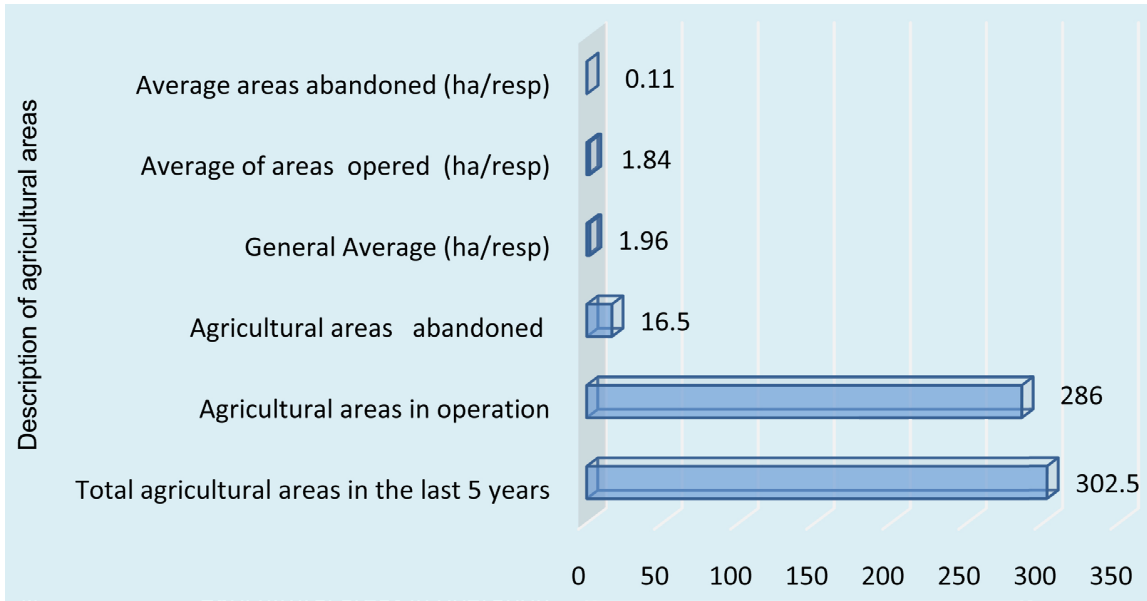

Figure 3. Size of respondents' agricultural areas in the municipality of Bobonaro.

Table 1. Land Factor (agricultural areas) of respondents.

\begin{tabular}{cccccc}
\hline No & Agricultural areas & $\begin{array}{c}\text { Hectare } \\
(\mathrm{ha})\end{array}$ & $\begin{array}{c}\text { Percentage } \\
(\%)\end{array}$ & $\begin{array}{c}\text { Owner } \\
\text { (respondent) }\end{array}$ & $\begin{array}{c}\text { Percentage } \\
(\%)\end{array}$ \\
\hline 1 & Total agricultural areas & 195 & 100 & & \\
2 & Worked area & 185 & 94.87 & & \\
3 & Abandoned area & 10 & 5.13 & & 100 \\
4 & Land status & & & 154 & \\
\hline
\end{tabular}

\subsubsection{The Respondents' Family Workforce}

It was found that the workforce media of each of the respondents (Figure 4) was composed of male and female. The male workforce is four people or more and the female workers are three or more within a family.

\subsubsection{Size and Productivity of the Interviewees' Cultivation Area}

Based on the data presented in Figure 5, the total cultivated productive area is 177.3 hectares "for rice production and 100.8 hectares" for corn production. It was found that the average rice field area per interviewee was 1.15 hectares and the agricultural areas for growing maize and other vegetables was around 0.65 hectares. Rice production level is 2.38 tons and corn production is 1.07 tons per hectare per harvest period. Farmers only grow rice and maize once a year, according to the normal growing season. During the dry season, they used rice paddy areas as pasture for livestock, due to lack of water in the second stage of rice planting. For this, the productivity of agricultural areas, especially rice-growing areas in the municipality of Bobnaro, is less used in the dry season for the cultivation of rice and other types of vegetables.

In agricultural production, activities are always based on a philosophy of classical thinking that inspires that the producers will spend little to obtain a high production, so that they can bring a better yield per harvest, thus ensuring the stability and continuity of the productive activity. 


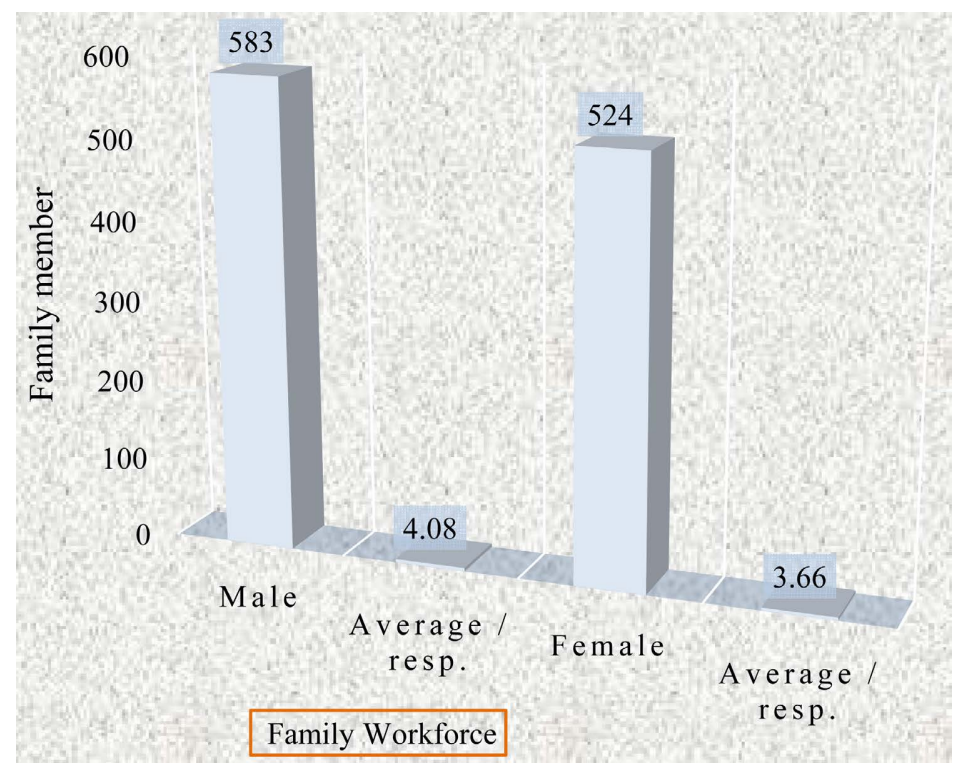

Figure 4. Classification of family workforce based on gender.

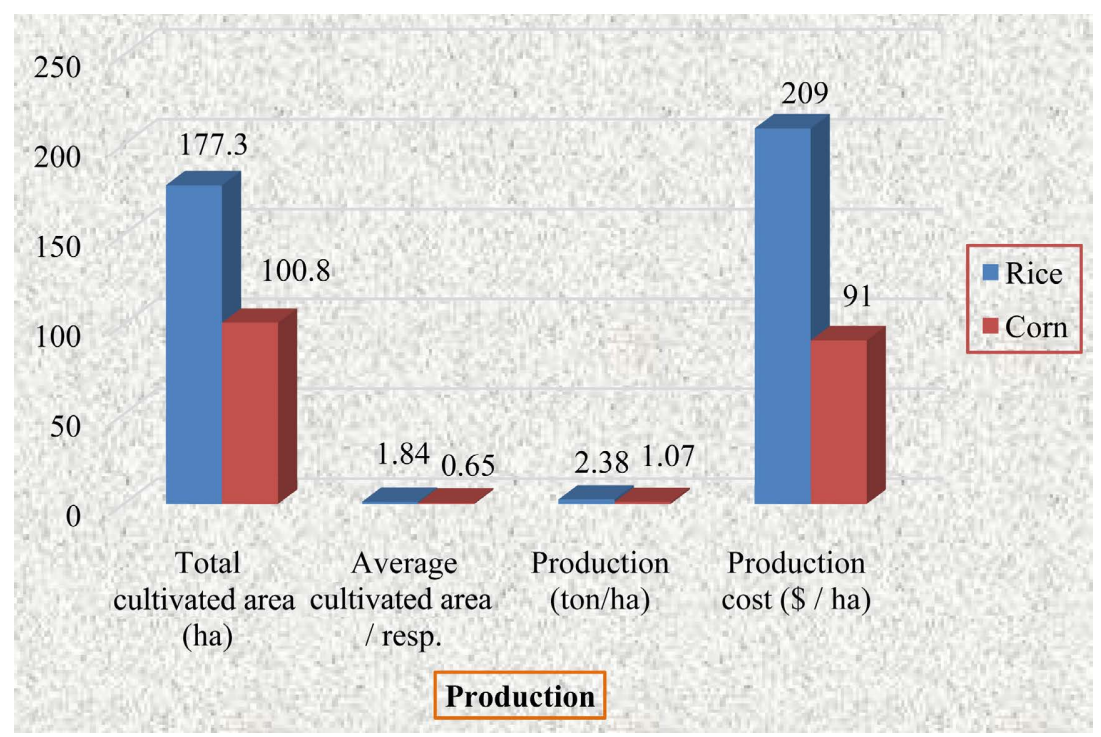

Figure 5. Productivity of agricultural area and production cost.

\subsubsection{Types of Animals Raised by Respondents}

The results of the analysis of the main types of animals and the stability of economic value in the local, regional and national market are presented in Table 2.

The data presented in Table 2 tends that the majority of respondents raise animals with high variation, however, most raise very little of all types of animals as specified in the descriptive analysis result mode.

\subsection{Factors That Influence the Sustainability of Agricultural Development}

The results showed that the factors that influence agricultural development, as presented in Figure 6. These factors are the main factors that greatly affect 


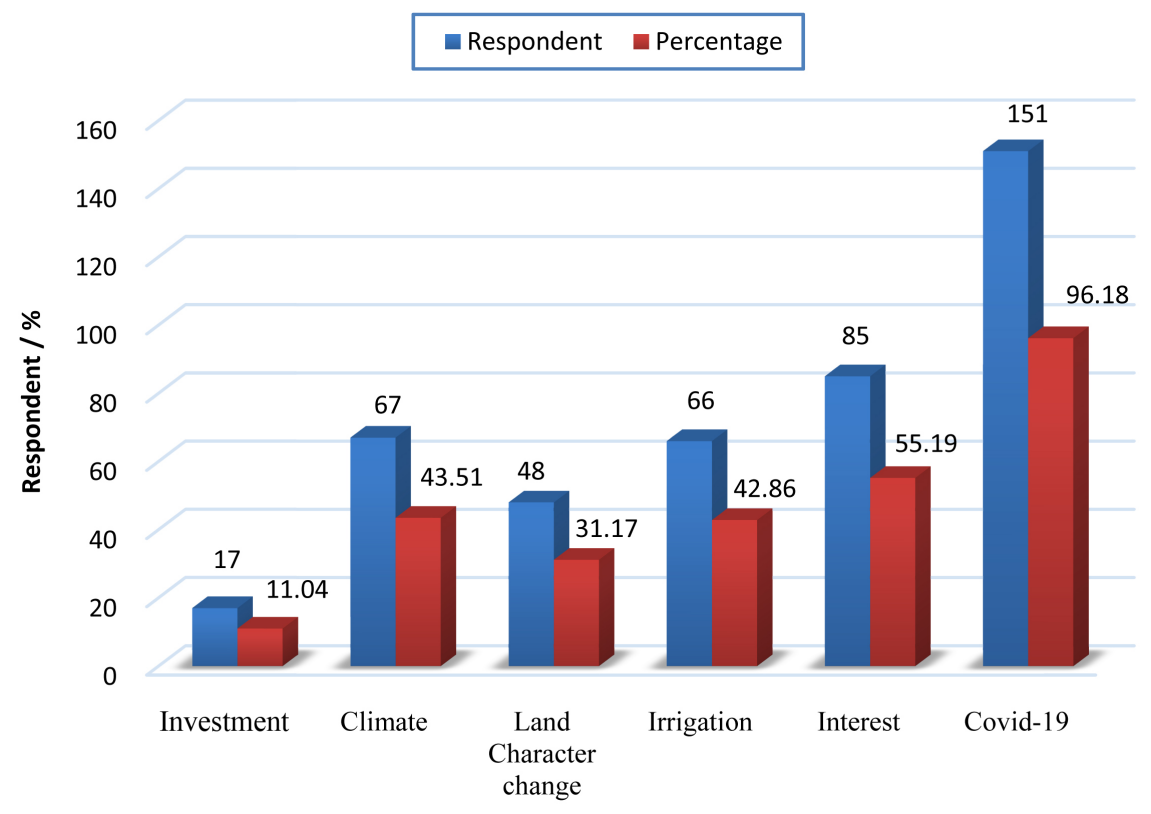

Figure 6. Factors that intimately influence agricultural development.

Table 2. Type of animals of respondents.

\begin{tabular}{ccccccc}
\hline \multirow{2}{*}{$\begin{array}{c}\text { Type } \\
\text { of Animals }\end{array}$} & \multicolumn{5}{c}{ Results of Descriptive Analysis } \\
\cline { 2 - 7 } & Resp. & Min. & Max. & Mode & Frequency & Valid \% \\
\hline Bali Cattle & 131 & 2 & 62 & 2 & 22 & 16.80 \\
Goats & 88 & 2 & 35 & 2 & 32 & 36.40 \\
Swine & 135 & 2 & 52 & 2 & 35 & 25.90 \\
Poultry & 141 & 2 & 80 & 5 & 17 & 12.10 \\
Buffalo & 20 & 2 & 40 & 2 & 6 & 4.30 \\
\hline
\end{tabular}

Obs. Resp.: respondent; Min.: Minimum; Max: Maximum.

agricultural production which has a very high negative impact on agricultural development. Natural factors are one of the factors that are very difficult to anticipate by farmers in the process of agricultural activities.

Around $43.51 \%$ of respondents stated that climate change factors greatly affect agricultural productivity, especially the lack of water flow so that it can complicate drainage management in irrigated rice fields. Around $45.19 \%$ of the total respondents stated that currently many people are not interested in working in the fields and gardening. In addition, almost $96.18 \%$ of respondents complained about the Covid-19 factor that could limit their movement in farming activities.

\section{Discussion}

The analysis results show that the productivity of the productive area is used only once a year, with rice production from 2.8 to 3.0 tons per harvest (Figure 2 
and Figure 3). Economically, productivity is the main indicator that relates production values to the factors used. The agricultural productivity found in the study refers to the increase in the amount of product that is not explained by the increase in the amount of inputs, but rather by gains in productive efficiency, which basically depends on technology. In one of its most familiar and well-known meanings, productivity is the relationship between production capacity and time. The average productive area used by each respondent is 1.84 hectares, which means that $94.36 \%$ of the general average productive area is in use. Thus, given that if a respondent can produce twice a year, the production volume of around 4 to 6 tons depends on production management, special access to irrigation, fertilizers and pest control [12].

The workforce is considered a determining factor in the development process of family farming so that they can increase and multiply the productivity of the productive factors. Respondents reported that in the agricultural development process, it is expected that, through the family's workforce, they will be able to reduce the number of expenses linked to productive activities. The average workforce of respondents obtained in this study (Figure 4) revealed that gender participation is balanced. Thus, it appears that it is a very strong and important indicator in the process of agricultural development in the country in general and especially in the municipality of Bobonaro. In subsistence agricultural activities in general, the entire family is involved in the production process, which, in a way, becomes responsible for subsistence and income generation for families and communities [13].

The average cultivated area per respondent for rice production is 1.15 hectares "and 0.65 hectares" for corn production. The rice production capacity per hectare is 2.38 tons and the corn production capacity is 1.07 tons per hectare. The production cost of rice per hectare is on average US\$209.00 and corn US\$91.00. Thus, it is estimated that the price of rice is US\$ $0.40 / \mathrm{kg}$ and of corn US\$ $0.25 / \mathrm{kg}$ (producer price), each producer can have an annual income of around US\$952.00 with the sale of rice and US\$251.75 in the sale of corn. In agricultural production, activities are always based on a philosophy of classical thinking that inspires that the producer will spend little to obtain a high production, so that he can bring a better yield per harvest, thus ensuring the stability and continuity of the productive activity.

Subsistence agriculture and livestock farming have been common and produced them permanent denominators of economic activity on the islands [14]. The authors further stated that, settlers introduced their plants, seeds, and animals, and according to the subsistence models from their places of origin. The interview results showed that not all producers have the same market access opportunity. About $38.96 \%$ of respondents answered that they did not have access to the market due to lack of basic infrastructure, transport and in the last 6 to 1 year due to the difficulty of locomotion for producers due to compliance with sanitary regulations and mandatory confinement during the Covid-19 pandem- 
ic. Limits to people's mobility within the country and across borders and containment measures are contributing to labor shortages in agricultural sectors. Demand also appears to be affected as consumers for go higher-value items in favor of ready-to-eat, easy-to-store staple foods. Changes in consumption habits have the potential to reshape eating habits and consumer behavior in the long term, especially if the containment measures are long-lasting.

Farmers still consider livestock as a secondary activity in the agricultural production activity. This consideration causes the animals to be released without technical control in terms of production, reproduction and health. In the animal production activity, one of the determining factors for success is the quantity and quality of food offered. The animals, like other living beings, need to feed on nutritious food to ensure daily life and high quality production. In addition, animals need to take good care in reproductive management and disease prevention to ensure good condition and high productivity [15].

The results show that, the main factors that do not support agricultural production that heightens the negative effects on agricultural development. Climate change, whose producers point out that the effect of this factor increases every year, and contributes negatively to the availability and volume of irrigation water, temperature fluctuations. Furthermore, the cultivation session is uncertain, making normal production difficult as in previous periods. Respondents also add that the capital factor also influences the productivity of farmers due to the lack of facilities and hired labor to support the progress of agricultural activity. This contributes to the increase in the rate of abandonment of productive areas and continues to reduce agricultural production.

The factors affecting rice and maize productivity include soil, environment and seed quality, lack of technical assistance, irrigation and drainage, and no interests affects the sustainability of agricultural production [12]. Among others, the willingness to work as a farmer is also the main problem for agricultural development. Respondents reported that, in their observations, many farmers begin to leave their profession with a farmer because they are able to obtain various government subsidies. They emphasize that it would be good if beneficiaries were regulated by some regulation on the positive use of these subsidies in productive activities, at least they would continue as food producers in rural areas.

\section{Conclusions}

The results of the study showed that the participation rate in agricultural activities is based on age and gender. About $94.87 \%$ of the productive area of respondents is a function of production, with an average of 1.84 ha per respondent and abandoned area only 0.11 ha per respondent, average production value rice 2.38 ton per ha and corn 1.07 ton per ha. $87 \%$ of producers raise the main types of animals such as cattle, pigs, goats with an average density per establishment of 2 to 5 animals. About $61 \%$ of producers have access to the market with normal prices for agricultural products. 
The main factors influencing less successful agricultural development in the municipality of Bobonaro, namely: those of nature with the greatest impact are climate change, which influence changes in cultivation sessions and in the characteristics of productive soils, availability of water for irrigation and availability of animal feed. On the socioeconomic side, it includes the willingness or interest of young people who want to work as farmers, lack investment (credits), the effect of subsidies and the Covid-19 pandemic. Concluding that the impacts of nature and socio-economic and cultural needs have reduced agricultural productivity, this is a major challenge for the development of the agricultural sector in the future. Based on the above findings, it is recommended that competent institutions address the following issues: implement a policy of bringing young agricultural graduates back to their villages of origin to become modern producers with subsidized support for at least one year; apply to subsidy recipients who must be productive in agricultural or food production activities; build dams to overcome water shortages in the dry season to make it easier for farmers to plant twice a year; offer low-interest loans to help farmers finance their activities and strengthen the market system and prices for agricultural products.

\section{Acknowledgements}

The work was funded by the East Timor National Institute of Science and Technology, INCT-TL. Therefore, the authors would like to thank you for all the support, guidance, and funding of the research.

\section{Conflicts of Interest}

The authors declare no conflicts of interest regarding the publication of this article.

\section{References}

[1] East Timor. Ministry of Finance (2015) General Directorate of Statistics. Timor-Leste Population and Housing Census. Population Distribution by Administrative Area. Volume 2-Population and Household Distribution. (In Portuguese)

[2] East Timor. Ministry of Agriculture and Fisheries-MAP (2019) Timor-Leste Agriculture Census, 2019. National Report on Final Census Results. (In Portuguese)

[3] Mosca, J. and Nova, Y. (2019) Agriculture: Thus, It Is Not Possible to Reduce Poverty in Mozambique. Rural Observer No. 80. October 2019.

[4] Guedes, S.N.R. (2006) Comparative Analysis of the Process of Transferring Public Lands to the Private Domain in Brazil and the USA: An Institutionalist Approach. Economics Magazine, 32, 7-37. (In Portuguese)

[5] Vieira, E.T.V., Guilherme, D.O., Itavo, L.C.V. and Tashima, L.C.N. (2016) Organic Agriculture: A Solution for the 21st Century? Brazilian Journal of Public Policy, 2016, 119-127. (In Portuguese)

[6] Denardi, R.A. (2001) Family Farming and Public Policies: Some Dilemmas and Challenges for Sustainable Rural Development. Agroecology and Sustainable Rural Development. Porto Alegre, 2, 56-62. (In Portuguese) 
[7] Costa, P., Costa, J.R., Wandelli, E.V., Bianchini, F. and Tavares, D. (2018) The Sustainable Development Goal 1. Poverty Eradication. EMBRAPA Contributions. Brasília, DF. (In Portuguese)

[8] Bragagnolo, C. and Barros, G.S.C. (2015) Dynamic Impacts of Production and Productivity Factors on the Agricultural Production Function. Journal of Rural Economics and Sociology, 53, 31-50. (In Portuguese)

[9] East Timor. Bobonaro in Number (2019) Statistics in the Municipality of Bobonaro. 3-4.

[10] Coutinho, C.P. (2011) Research Methodology in Social and Human Sciences: Almedina Editions. 344 p. (In Portuguese)

[11] Sugiyono (2014) Educational Research Methods Quantitative, Qualitative, and R\&D Approaches. Alfa Beta, Bandung, 65. (In Indonesian)

[12] Moniz, A.C. (2021) Productivity, Profitability and Energy Use Efficiencies of Hybrid and Traditional Varieties of Rice (Oryza sativa L.), Maize (Zea mays) and Sorghum (Sorghum bicolor) in Maliana, Bobonaro Timor-Leste.

[13] Cumaru, R.A. (2006) Technical Report-Social and Environmental Diagnosis of Communities of the Middle Juruá Extractive Reserve. 2006. CNPT/IBAMA. (In Portuguese)

[14] Barrera, V., Monteros-Altamirano, Á., Valverde, M., Escudero, L., Allauca, J. and Zapata, A. (2021) Characterization and Classification of Agricultural Production Systems in the Galapagos Islands (Ecuador). Agricultural Sciences, 12, 481-502. https://doi.org/10.4236/as.2021.125031

[15] Bidura, I GUST.NYM.GDE and Gomes, G.S. (2019) Nutritional Management of Pork. Needs and Deficiency of Food Substances. Swasta Nulus. Denpasar Bali. (In Indonesian) 